\title{
Experimental Studies on Two Stroke SI Engine by Using Novel Piston and Gasoline Blends
}

\author{
A.V.N.S. Kiran*, B. Santosh Kumar, M. Loknath, S.M. Saleemuddin, S. Nagendra \\ Annamacharya Institute of Technology and Sciences, Rajampet, Kadapa Dist. A.P, India
}

Corresponding Author Email: kiran.avns321@gmail.com

https://doi.org/10.18280/jesa.520102

Received: 13 November 2018

Accepted: 22 January 2019

\section{Keywords:}

performance parameters, un burnt hydro carbons emissions, CO emissions, ethanol, and methanol

\begin{abstract}
It is well known fact that thermal efficiency of the two stroke engines on road usually ranges from nearly $35 \%$ to $45 \%$ and remaining energy is dissipated to the surrounding media. Therefore, it becomes the primary need to improve the engine performance. From the past decade and so and exhaustive research is carried by various researchers towards attaining higher level of the engine performance by doing certain modifications of the engine component family. Majority of researches focused on adding of coatings on pistons and by using the blends the performance characteristics are studied. The main aim of the present work is to develop a novel piston that reduces the percentage level of pollutants release to atmosphere and aid in improving the performance of the system. The work mainly focused on influence of novel piston and different blends in enhancing the engine performance and suppressing the level of emissions, thereby reducing the global working effects. The experiments are performed on single cylinder two stroke SI engine by using conventional piston, novel piston-1 (Bi metallic piston with copper piston crown), novel piston-2 (Bi metallic piston with $\mathrm{Br}$ piston) and different blends. It is noticed that the emission levels of pollutants got reduced by using novel piston-1and E20 blend and performance wise also novel piston- 1 and M20 blend gave the best results in overcoming the burning issues in two stroke SI engines.
\end{abstract}

\section{INTRODUCTION}

Two stroke SI engines take part in the field of transport and agriculture, but with the increasing demand of fossil fuels its limited reserves environmental pollution and lower thermal efficiency (around $30 \%$ to $40 \%$ ) led to the development of alternative fuels and modifications in engine design. Several researches are carried in improving the engine performance by using various alternative fuels for controlling the emissions like $\mathrm{CO}$ and UBHC etc. in the field of two stroke engines.

The engine performance can be greatly enhanced by controlling the thermal energy dissipation from combustion chamber to surroundings. Many researchers have done their work on applying coatings in the combustion chamber.

Also the use of petroleum fuels release harmful emissions which causes global warming effects and health related problems. The disadvantages ultimately led to the path for development of alternate fuels keeping in mind of controlling emissions and supporting the demand for running automobiles by alternate fuels.

N.Nedunchezhian et.al discussed about the plasma coating method coating on the cylinder head and piston. The selected catalyst is copper. The in cylinder coating of copper catalyst reduces the fuel consumption. There is $10 \%$ improvement in fuel economy at $2.0 \mathrm{~kW}$ load condition achieved. The catalyst activity is higher at higher load conditions. The combustion rate is increased at all load conditions. The combustion parameters indicate a faster and cleaner combustion when engine is coated with the catalyst. The $\mathrm{HC}$ emissions are reduced at significant level [1].

Michel Anderson Marr et.al done his investigations on metal and ceramic thermal barrier coatings for SI engines. It shows a reduction in peak heat flux with the thermal barrier coatings by $69 \%$ and YSZ by $77 \%$ relative to the conventional surface. Also from the experimental observation the metal TBC gave better performance when compared with the uncoated piston and YSZ coated piston [2].

Narasimha Kumar, S, et al. has discussed about the copper coat on piston crown of 300 microns of thickness by using ethanol as blend to petrol to find the engine performance characteristics. The performance parameters like volumetric efficiency, Thermal efficiency are increased by $3 \%$ and $22 \%$ respectively with gasoline and ethanol blend, with coated engine(copper) in contrast with pure gasoline operation and emission characteristics. The emissions like UBHC and carbon monoxide during exhaust of engine got decreased by $25 \%$ and $30 \%$ respectively in conventional engine with gasoline and ethanol blend when contrast to pure gasoline operation. The pollutants decreased by $20 \%$ with

Catalytic coated engine when contrast to conventional engine for both the test fuels [3].

M. Dharani Kumar et.al discussed about the copper coated piston to lessen the exhaust emissions for the two stroke SI engines. The exhaust gases emissions namely $\mathrm{CO}, \mathrm{HC}, \mathrm{O}_{2}$, $\mathrm{CO}_{2}$ and have been reduced to $1.02 \%, 582 \mathrm{ppm}, 15.37 \%$ and $1.42 \%$ correspondingly by using Emission Gas Analyzer [4].

Sailesh Dhomne et al. done experimental investigations about the thermal barrier coatings on piston for two stroke engines to increase the engine performance parameters of specific fuel consumption is reduced by $9.73 \%$, and thermal efficiency increased by 12.73 , Therefore $\mathrm{Cr}-\mathrm{Ni}-\mathrm{Ce} \mathrm{TBC}$ is an efficient method to improve performance of two stroke SI 
Engine [5].

Dr. K. Kishor discussed the comparative performance parameters of copper coated piston of thickness 300 microns and the effect of methanol blended gasoline for IC engines. Brake Thermal efficiency (BTE) increased by $22 \%$ and Volumetric efficiency enhanced to $4 \%$ with alcohol gasoline blend operation in CCCC over regular gasoline use in CE [6].

Prof. Parvez F. Agwan et al. made an experimental investigation on thermal barrier coatings with composition of nickel chromium and $\mathrm{Al}_{2} \mathrm{O}_{3}$ on piston crown to lessen the exhaust emissions and improving the engine efficiency. The thermal efficiency is increased by $13.75 \%$. Fuel consumption mass is decreased by $6.02 \%$. BSFC is reduced to $9.84 \%$ between regular and coated engine [7].

Bhupendra C. Sandhu et al. made a review about coatings in SI engine. It is found from from the survey that Zirconia, Plasma spray coating and Alumina are the most appropriate materials for thermal barrier coatings in combustion chamber [8].

Dr. K Kishor highlited the analysis of exhaust emissions with copper coated piston of 300 microns and operating with methyl alcohol blended gasoline for IC engine. The Unburnt hydrocabons and $\mathrm{CO}$ emissions decreased by $42.8 \%$ and UBHC emissions decreased by $44 \%$ with alcohol gasoline blend operation in CCC over regular gasoline operation in $\mathrm{CE}$ [9].

S. Sathyamoorthi et al. discussed about the ceramic coatings of materials Zirconia with thickness of 100 microns on piston crown. The Engine performances like indicated thermal efficiency \& brake thermal efficiency have improved by $11.14 \%$ and $5.89 \%$ respectively. The results obtained are contrasted between Zirconia coated piston and regular piston [10].

S. Krishnamani et al. discussed about the thermal barrier coatings of alluminium alloy piston using YSZ and $\mathrm{MgZrO}_{3}$ and also carried the thermal analysis using Finite Element Method (FEM). It is found that the substrate temperature of the coated piston with $\mathrm{YSZ}$ and $\mathrm{MgZrO}_{3}$ and is reduced by $17 \%$ and $25 \%$ when contrast with regular aluminum piston [11].

ArunMagadam et al. investigated on modified piston to find the effect of high refractive index material coating for two stroke engines. The engine performances like sfc on novel piston with 10 micron coating is lessened by $3.64 \mathrm{~kg} / \mathrm{Kw}-\mathrm{hr}$, and brake thermal efficiency for novel piston at 10 microns coating is increased by $0.0035 \mathrm{Kw}$, when verified with regular piston [12].

M. Ponmurugan et al. discussed about the partially ceramic coatings on piston crown of material composition AlSi \& $\mathrm{MgO}-\mathrm{ZrO}_{2}$ to know the effect of thermal behavior of piston. Thermal analysis is examined on a SI engine piston, manufactured with the materials of steel. \& AlSi alloy and piston, coated with $\mathrm{MgO}-\mathrm{ZrO}_{2}$ material by ANSYS. It is found that thermal barrier coatings support in improving the engine performance. [13].

Hafiz Liaqat Ali et al. discussed about the thermal barrier coatings and material composition $\mathrm{TiO} 2$ and $\mathrm{YSZ}$ with $0.5 \mathrm{~mm}$ thickness along with the Compressed Natural gas (CNG) to know the performance parameters of an engine. It is found that indicated thermal efficiency got increased by $9.78 \%$ by using YSZ and $\mathrm{TIO}_{2}$ and indicated specific fuel consumption got reduced by $16.8 \mathrm{~g} / \mathrm{kW} \cdot \mathrm{h}(9.1 \%)$ than regular piston working under same conditions [14].

Er. Ganesh V. Thorve et.al discussed about the reduction of exhaust emissions from two stroke SI engines by using TBC on piston was reviewed. For an effective thermal coating the material should have high oxygen resistance, high melting point, high corrosion resistance, high thermal expansion coefficient, low thermal conductivity and phase stability and high strain tolerance. [15]

Shailesh Dhomne et al. made a review about the thermal barrier coatings with different material composition for IC engines to evaluate the engine performance and engine emission characteristics. It has a favourable effect on the exhaust emission and power of engine [16].

Abhinav Lal et al. discussed a review about the thermal barrier coatings on piston crown for SI engines to reduce exhaust emissions and improve the engine performance parameters. In this paper the author explained about the, temperature, pressure changes, piston undergoing stress and mechanical and thermal fatigue from his findings a thorough analysis and modifications of piston are required in identifying the failure and lessening the problem. [17].

T. Karthikeya Sharma studied emission analysis and performance on the effect of TBC on cranny and wall stifle regions temperature and argon gas in the inlet air mixture. It is found that bsfc decreases as the argon concentration increases. There is a decrement in volumetric efficiency with the increase in $\operatorname{argon}(\%)$. As the Ar concentration increases the emission index of oxygen $\left(\mathrm{O}_{2}\right)$, nitrogen oxide $(\mathrm{NO})$, and carbon dioxide $\left(\mathrm{CO}_{2}\right)$ were decreased. Increase in Carbon monoxide emissions is seen with increase in argon (\%) to intake air. The exhaust gaseous temperature also decreases with the increase in argon concentration. In correlation to SE lower BSFC has been noticed in TBCE [18].

S Pal, A Deore discussed about the analysis and experimental investigations about the ceramic coatings on piston crown in the IC engines. From his findings zirconia ccan be regarded as superior option when compared to titania ceramic powders and alumina as thermal barrier coatings. Surface roughness test also revealed that by the application of $\mathrm{TBC}$ there is increase the roughness in very small amounts and does not alter the engine operations [19].

From the findings of above research carried by various authors it is noticed that not much of research work is carried in modification of piston design for enhancing the engine performance and usage of a fewer blends as a replacement to petrol for controlling the emissions.

In the present work to overcome the above difficulties the bi metallic piston is made with copper and brass plate fitted alternatively over the piston crown and with different blends the performance of system and emissions are measured.

\section{EXPERIMENTAL PROCEDURE}

Piston is important part of engine where combustion process is carried. In the present work the piston crown is machined up to $15 \mathrm{~mm}$ from top and two plates namely copper and brass of $15 \mathrm{~mm}$ thickness are fitted on machined top surface of piston (i.e., piston crown) for evaluating the engine performance.

The procedure is as follows.

Initially with the conventional setup and with varying blends the engine performance is measured. Next the copper plate and brass plate are fitted alternatively over the modified piston crown and performance of the engine is studied with different blends. 
Table 1. Test engine specifications

\begin{tabular}{cc}
\hline ITEM & SPECIFICATIONS \\
\hline Engine & Single cylinder 2-stroke S.I engine \\
Cylinder bore & $50.5 \mathrm{~mm}$ \\
Stroke length & $50.5 \mathrm{~mm}$ \\
Engine speed & $5000 \mathrm{rpm}$ \\
Compression ratio & $6.7: 1$ \\
Type of cooling system & Air cooling \\
\hline
\end{tabular}

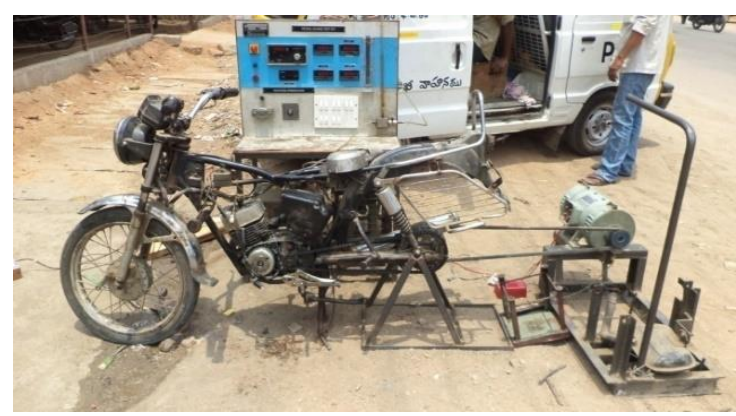

Figure 1. Experimental setup

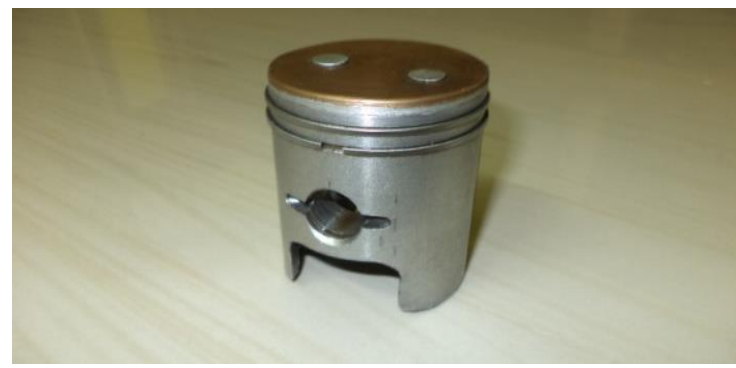

Figure 2. Bimetallic piston

Table 2. Fuels used for test

\begin{tabular}{cc}
\hline blends Used & Proportion \\
\hline PG & $100 \%$ Pure Gasoline \\
E20 (B1) & Ethanol $20 \%+$ Petrol $80 \%$ \\
M20 (B2) & Methanol $20 \%+$ Petrol $80 \%$ \\
\hline
\end{tabular}

\section{RESULTS AND DISCUSSIONS:}

\subsection{Results}

Load Vs HC

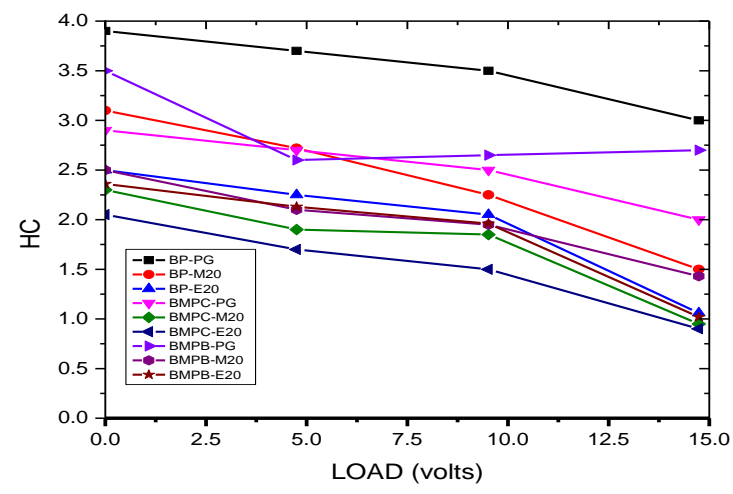

Figure 3. Load Vs HC
Unburnt hydrocarbon (UHBC) emissions:

The figure. represents the measured unburned hydro carbon emissions for base piston and bi metallic piston for $\mathrm{Cu} \& \mathrm{Br}$. The blends E20 \& M20 has decreased UBHC emissions of bi metallic piston when compared to base piston. Withe involvement of high temperature, the engine will contain enough amount of oxygen and thus reacting with $\mathrm{HC}$ emissions. The outcome shows $\mathrm{HC}$ is divided in to $\mathrm{H}$ and $\mathrm{C}$ by mixing with $\mathrm{O}_{2}$ thereby reducing the $\mathrm{HC}$ emissions. While comparing UBHC emissions it is noticed that the emissions are decreased by $10-15 \%$ by using $\mathrm{Cu}$ bimetallic piston for E20 blend.

\subsection{Load Vs CO}

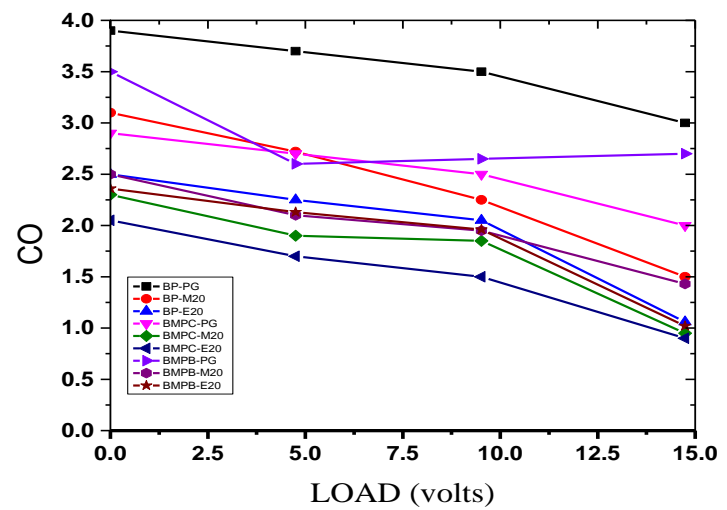

Figure 4. Load Vs CO

Carbon mono oxide (CO) emissions:

The fig shows the carbon monoxide emissions at different loads. From the findings the $\mathrm{CO}$ emissions are reduced in $\mathrm{Cu}$ plated bi metallic piston when comparing to the $\mathrm{Br}$ plated bi metallic piston\& base piston due to proper combustion. At involvement of high temperature $\mathrm{C}$ combines easily with $\mathrm{O}_{2}$ and lessening $\mathrm{CO}$ emission. This difference of scale is sustained up to $60 \%$ of the load than the $\mathrm{CO}$ emissions and decreased up to $7-12 \%$.

\subsection{Load Vs Specific Fuel Consumption (SFC)}

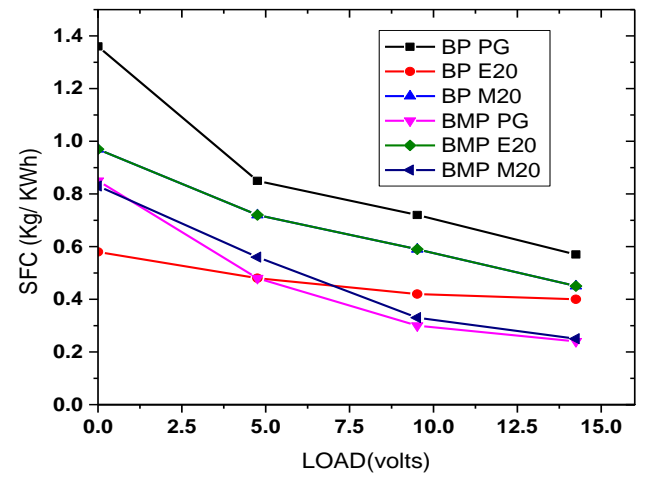

Figure 5. Load Vs SFC

Specific Fuel Consumption:

The infuence of using ethanol and methanol gasoline blends on BSFC is presented in the load vs. bsfc graphs. From the graphs SFC reduces as the parameter toeque of engine increases. 
From the graphs by using ethanol and methanol on base piston and bi metallic piston with the proportions of $20 \%$ and pure gasoline. There is gradual decrease of the specific fuel consumption when comparing to the base piston and bi metallic piston. The overall fuel consumption is decreased by $10-12 \%$ bythe bimetallic piston than the base piston.

\subsection{Load Vs Break Thermal Efficiency}

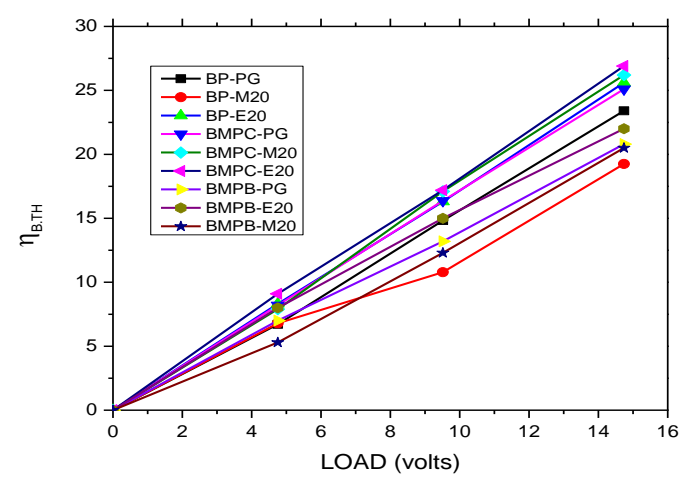

Figure 6. Load Vs BTH

\section{Break Thermal Efficiency:}

The effect of using the ethanol and methanol blended fuels on brake thermal efficiency is presented in the garph load vs. brake thermal efficiency. As shown from the graph the brake thermal efficiency increases by using the ethanol and methanol.

The overall brake thermal efficiency is enhanced by $1.02 \%$ when comparing the base piston to bimetallic piston with the blends of ethanol and methanol of $20 \%$ and pure gasoline.

\subsection{Discussions}

(1). The copper and brass plate on the piston crown as a bi metallic piston. The reason is copper and brass will behave as an accelerator in the combustion chamber, there by facilitating good fuel combustion and forming to $\mathrm{CO}_{2}$ in place of $\mathrm{CO}$. More over copper is also a ductile metal with very high thermal conductivity and electrical conductivity.

(2). Methanol brake up in engine combustion chamber forming hydrogen, and assist the fuel-air mixture in burning quickly and raising the combustion velocity, making the complete combustion of the carbon in the fuel to $\mathrm{CO}_{2}$, also $\mathrm{CO}$ to $\mathrm{CO}_{2}$ formation making lean mixture highly combustible, and reducing $\mathrm{CO}$ emissions.

(3). Also ethanol blend mixes with the oxygen during the combustion process, produces carbon dioxide, heat and water

$$
\mathrm{C}_{2} \mathrm{H}_{5} \mathrm{OH}+3 \mathrm{O}_{2} \rightarrow 2 \mathrm{CO}_{2}+3 \mathrm{H}_{2} \mathrm{O}+\text { Heat. }
$$

\section{CONCLUSIONS}

The two stroke SI engine is examined performance and emissions wise. The findings after the experimentations are as follows:

(1). The unburnt $\mathrm{HC}$ emissions are studied and it is noticed that emissions were reduced by $10-15 \%$ by using bi metallic $\mathrm{Cu}$ piston and E20 fuel than conventional piston and bi metallic $\mathrm{Br}$ piston. Due to high thermal energy release, the $\mathrm{HC}$ will break into $\mathrm{C} \& \mathrm{H}$ atoms and upong mixing with $\mathrm{O}_{2}$ and releses cabon dioxide and water and there by lessening the hydrocarbo emissions.
(2). The emissins of $\mathrm{CO}$ were reduced by 7-12\% at different loads by using bi metallic $\mathrm{Cu}$ piston and E20 fuel than conventional piston and bi metallic $\mathrm{Br}$ piston. This is because at high temperatures $\mathrm{C}$ will easily combine with $\mathrm{O}_{2}$ forming as $\mathrm{CO}_{2}$ and thereby reducing the $\mathrm{CO}$ emissions.

(3). Due to development of high engine torque the SFC got decreased and it is low by $10-12 \%$ for bi metallic $\mathrm{Cu}$ piston \& M20 fuel when compared with bi metallic $\mathrm{Br}$ piston and conventional piston.

(4). The overall thermal efficiency got increased by using bi metallic $\mathrm{Cu}$ piston and M20 by $1.02 \%$ than conventional piston and also noticed higher for bimetallic $\mathrm{Cu}$ piston when compared with bimetallic $\mathrm{Br}$ piston.

\section{FUTURE SCOPE}

The experimental works can be further extended by using different blends, coatings on modifying piston design etc for verifying the percentage level of emissions and engine performance in two stroke SI engines.

\section{REFERENCES}

[1] Nedunchezhian N, Dhandapani S. (2001). Effect of incylinder catalytic coating on the performance of a two stroke spark ignition engine. International Journal of Engineering \& Materials Sciences 8(1): 1-7.

[2] Marr A, Wallace JS, Memme S, Chandra S, Pershin L, Mostaghimi J. (2010). An investigation of metal and ceramic thermal barrier coatings in a spark-ignition engine. Master Thesis, Applied Science Graduate Department of Mechanical and Industrial Engineering, University of Toronto. https://doi.org/10.4271/2010-012090

[3] Narasimha KS, Krishna MVSM, Murthy VK, Reddy DN, Kishor K. (2011). Performance of copper coated two stroke spark ignition engine with Gasohol with Catalytic converter with different catalysts. International Journal of Applied Engineering Research, Dindigul 2(1): 205218.

[4] Dharanaikumar M, Chandraboopathi R, Ragu S, Vijayaraghavan K. (2013). Emission analysis of copper coating in piston crown and cylinder head engine. International Journal of Innovative Research in Science, Engineering and Technology 2(1): 328-333.

[5] Dhomne S, Mahalle AM, AyazAfsar M. (2015) Experimental and computational investigations on piston coated externally scavenged S.I. engine. IOSR Journal of Mechanical and Civil Engineering (IOSR-JMCE) 81-85.

[6] Kishor K. (2014). Comparative studies on performance parameters of two stroke spark ignition engine with copper coated piston with methanol blended gasoline. International Journal of Mechanical Engineering and Technology (IJMET) 5(12): 139-145.

[7] Agwan F, Pande SA. (2015). An experimental investigation of piston coating on internal combustion engine. International Journal for Scientific Research \& Development (IJSRD) 3(8): 645-648.

[8] Sandhu BC, Patil US. (2015). Application of ceramic coating for combustion chamber equipments of IC engine: A review. International Journal of Science, Engineering and Technology Research (IJSETR) 4(12): 
4043-4047.

[9] Kishor K. (2016). Analysis of exhaust emissions from two stroke spark ignition engine with copper coated piston operating with methyl alcohol blended gasoline. International Journal of Science and Research (IJSR) 5(1): 1391-1393.

[10] Sathyamoorthi S, Prabhakaran M, Abraa SAM. (2016). Numerical investigation of ceramic coating on piston crown using Finite Element Analysis. International Journal of Scientific Engineering and Applied Science (IJSEAS) 2(4): 258-263.

[11] Krishnamani S, Mohanraj T. (2016). Thermal analysis of ceramic coated aluminum alloy piston using finite element method. Indian Journal of Science and Technology 9(22):

$1-5$. http://dx.doi.org/10.17485/ijst/2016/v9i22/91338

[12] Magadum A, Sridhara SN. (2017). The performance and emission test for modified piston of 2 stroke petrol engine. International Journal of Scientific and Research Publications $\quad 7(9)$ : 350-354. http://dx.doi.org/10.13140/RG.2.2.16754.61123

[13] Ponmurugan M, Sundaramahalingam A, PrakashRubert S, Kumar MR. (2018). Effect of constructional change in IC engine piston by partially ceramic coating. International Journal of Advance Engineering and Research Development 5(2): 1-6.
[14] Ali HL, Li FB, Wang Z, Shi JS. (2018). Effect of ceramic coated pistons on the performance of a compressed natural gas engine. 5th International Conference on Mechanics and Mechatronics Research (ICMMR 2018) 417: $\quad 012021 . \quad$ https://doi.org/10.1088/1757$899 X / 417 / 1 / 0120211-8$

[15] Er GV. Throve, SB. (2018). Experimental analysis of thermal barrier coatings in two stroke SI engines. IJARIIE 4(3): 989-992.

[16] Dhomne S, Mahalle AM. (2018). Thermal barrier coating materials for SI engine. Journal of Material and Research and Technology 1-6. https://doi.org/10.1016/j.jmrt.2018.08.002

[17] Lal A, Kumar M. (2017). A survey approach of optimum design of piston. International Journal of Engineering Sciences \& Research Technology 510-514. https://doi.org/10.5281/zenodo.817895

[18] Sharma TK. (2015). Performance and emission characteristics of the thermal barrier coated SI engine by adding argon inert gas to intake mixture. Journal of Advanced $\quad$ Research 6 : 819-826. http://dx.doi.org/10.1016/j.jare.2014.06.005

[19] Pal S, Deore A, Choudhary A, Madhwani V, Vijapuri D. (263). Analysis and experimental investigation of ceramic powder coating on aluminium piston. IOP Conf. Series: Materials Science and Engineering 263: 1-18. http://dx.doi.org/ 10.1088/1757-899X/263/6/062071 